\title{
How do you feel when you see a list of prices? The interplay among price dispersion, perceived risk and initial trust in Chinese C2C market
}

Author names and affiliations

(1) Kewen Wu

Department of Computer Science, University of Saskatchewan

(2) Julita Vassileva

Department of Computer Science, University of Saskatchewan

(3) Zeinab Noorian

Department of Computer Science, University of Saskatchewan

(4)Yuxiang Zhao

School of Economics and Management, Nanjing University of Science and Technology

Corresponding author

Kewen $\mathrm{Wu}$

Email: Kewen-wu@163.com

\begin{abstract}
The issues of trust fraud, product genuineness and price dispersion jointly make Chinese C2C buyers difficult to identify trustworthy sellers with a low price. Little is known about the generation of initial trust when buyers search products and receive lists of widely ranged prices. This study proposes a theoretical model to explain how price dispersion interacts with other factors in $\mathrm{C} 2 \mathrm{C}$ purchase, such as initial trust, perceived risk, perceived value and purchase intention. Product type is considered as a moderator. 261 students were invited in a survey-based experiment. The results from PLS analysis show that price dispersion negatively affects perceived value, whilst, positively affects perceived risk, which further influences perceived value negatively. Price dispersion also negatively influences initial trust through perceived risk. Moreover, the negative effects of price dispersion are stronger when buyers purchase high-touch products.
\end{abstract}

Keywords: consumer to consumer, trust, price dispersion, purchase intention, perceived risk 


\title{
How do you feel when you see a list of prices? The interplay among price dispersion, perceived risk and
} initial trust in Chinese C2C market

\begin{abstract}
:
The issues of trust fraud, product genuineness and price dispersion jointly make Chinese C2C buyers difficult to identify trustworthy sellers with a low price. Little is known about the generation of initial trust when buyers search products and receive lists of widely ranged prices. This study proposes a theoretical model to explain how price dispersion interacts with other factors in C2C purchase, such as initial trust, perceived risk, perceived value and purchase intention. Product type is considered as a moderator. 261 students were invited in a survey-based experiment. The results from PLS analysis show that price dispersion negatively affects perceived value, whilst, positively affects perceived risk, which further influences perceived value negatively. Price dispersion also negatively influences initial trust through perceived risk. Moreover, the negative effects of price dispersion are stronger when buyers purchase high-touch products.
\end{abstract}

Keywords: consumer to consumer, trust, price dispersion, purchase intention, perceived risk

\section{Introduction}

Chinese online consumer-to-consumer (C2C) market has been growing rapidly in recent years. For example, Taobao, who owns 90\% Chinese C2C market share, its transaction volume grows from 4.7 million USD in 2003 to 142 billion USD in 2013 (Iresearch, 2013). Despite the huge amount of transactions, the Chinese C2C market is plagued by serious issues of product genuineness and trust manipulation, leading to a high level of transaction risk. A recent official report shows that $62.75 \%$ of Taobao products are not genuine, e.g., refurbished products are claimed to be brand new products, and the products without any quality certification (Saic, 2015). Moreover, previous statistics report that the detected transactions which manipulated reputation in Taobao occupied as high as $47 \%$ of all the transactions during 2008 and 2009. And there exist over 1000 active companies which provide 
services to increase sellers' reputation and whitewash negative feedback (Zhang et al., 2012). Therefore, how to find a trustworthy seller to buy good product becomes a critical issue faced by C2C buyers.

Trust has been widely recognized as a key factor in online purchase (Ba \& Pavlou, 2002). It determines buyers' intention to purchase and their choice of sellers to visit. Since C2C buyers are unable to fully identify either sellers or products before purchase, they use a variety of available cues (e.g., price, reputation, reviews) to support their trust judgement (Hsieh \& Tsao, 2014; Roest \& Rindfleisch, 2010). Among these cues, price is considered to be important in evaluating future product or service experience and in shaping attitude towards the seller (Han \& Ryu, 2009), because people frequently assume that price and quality are highly correlated (Jin \& Kato, 2006; Kardes et al., 2004; Kim et al., 2012). Given the fact that reputation and reviews can be manipulated, it is reasonable to expect that price-related information to be more important in buyers' trust judgement.

In a $\mathrm{C} 2 \mathrm{C}$ market, buyers can easily retrieve a list of price quotes from various vendors of a given product, and they form their own internal reference prices based on these prices. Price dispersion refers to the distribution of prices of a product across sellers at a given point in time in the market (Pan et al., 2004). Studies have shown that buyers are motivated to execute effort to figure out the reasons that lead to price dispersion (or the reasons why some prices are higher or lower than internal reference prices) (Biswas, 2004). Attribution theory (Heider, 2013), which concerns how people rationalize an ambiguous situation, serves as a suitable theoretical basis to understand how buyers explain price dispersion within the trust development process.

Attribution theory segments the factors that cause an event to stimulus and non-stimulus causes. For example, buyers would form a favorable attitude if they attribute a high price (an event) to the seller's good service quality (stimulus factor) rather than opportunism (non-stimulus factor). Otherwise, a negative attitude would be formed. Such attitude towards pricing is actually a belief induced from buyers' internal decision process that whether the seller's pricing behavior is trustworthy or not.

In this paper, we intended to investigate how price dispersion influences trust. The scenario that describes our interest is: how buyers decide to trust a set of sellers when they search a product and receive a list of widely ranged prices, rather than a list of narrowly ranged prices? We choose initial trust because the perception of price dispersion happens in the price-seeking stage, and trust in this stage shows a general willingness to conduct a transaction with one of the sellers in the list. Additionally, we try to differentiate the effects of price dispersion under different types of products: the "low-touch” products, and the "high-touch" products. The low-touch 
products are standardized goods where not much effort is required to evaluate their quality before purchase. The high-touch products require buyers to touch or experience before purchase (Levin et al., 2003).

\section{Literature Review}

C2C buyers' trust development process involves an analysis of price-related information (e.g., price range, distribution) and an evaluation of the potential transaction risk (e.g., a low-priced product may performance poorly). Buyers then balance the importance of the low/high price of the target product and the perceived potential risk, and generate a purchase intention. Therefore, our literature review mainly focuses on price dispersion, perceived risk, trust and perceived value.

\subsection{Price Dispersion}

Current work on price dispersion largely falls into four streams: 1) comparisons between online and offline price dispersion, 2) persistence of online price dispersion, 3) sources of online price dispersion, and 4) consequences of price dispersion. The first three types were derived from Pan's (2004) review, and they are in line with the summaries presented in many studies (Ghose \& Yao, 2011; Maxwell et al., 2011). The fourth type, which reflects an emerging direction, has not been explicitly summarized in previous studies.

Earlier economic viewpoints predicted that online marketing would operate more efficient and friction-free than offline marketing (e.g., online buyers can easily obtain price quotes from different sellers), and therefore the level of price dispersion in online markets should be lower than that in offline market (Baylis \& Perloff, 2002). However, although the results from previous studies are not consistent, this theoretical prediction has been challenged. Some studies have found that online price dispersion is higher than offline price dispersion (Ancarani \& Shankar, 2004; Brynjolfsson \& Smith, 2000; Clay et al., 2002); others have found that offline price dispersion is higher (Brown \& Goolsbee, 2002; Brynjolfsson \& Smith, 2000); and still others have found no significant difference between online and offline price dispersion (Scholten \& Smith, 2002). Moreover, as many sellers offer both online and offline retailing, researchers are motivated to explore how multichannel retailing influences price dispersion. The obtained results are inconsistent. For example, Pan (2003) finds that multichannel retailers have a lower level of price dispersion than do pure online retailers; while Xing et al., (2006), and Tang \& Xing (2001) find a reverse result. The different results may be due to different measurement of price dispersion, product categories, and market differences, etc. 
The theory of immature market suggests that price dispersion may be a reflection of random noise of an immature market and price range will be narrow over time (Baylis \& Perloff, 2002). But many studies repudiate this theory and find that although Internet market evolves as time progresses, price dispersion remains persistent (Pan et al., 2002; Pan, et al., 2004; Ratchford et al., 2003; Xing, et al., 2006).

Since online price dispersion is significant and persistent, researchers have attempted to explore the sources of online price dispersion. Generally speaking, homogeneity in sellers and products, search costs and information asymmetry are considered as three core reasons (Ghose \& Yao, 2011). Table 1 presents a brief summary of current studies on the sources of online price dispersion.

Studies on effects of online price dispersion are limited. However, their results show that high levels of price dispersion bring uncertainty, such as perception of transaction risk (Biswas \& Burman, 2009), increased search effort (Biswas, 2004), and difficulty to perceive price (Chen \& Bei, 2005; Lai et al., 2006).

\section{Insert Table 1 Here}

In C2C context, however, the sources of price dispersion and effects of price dispersion have received little attention. Based on the aforementioned previous studies, some factors such as quality of the product and services, reputation and pricing strategy can cause price dispersion. However, fraud can also lead to (abnormal) price dispersion (Zhang, et al., 2012). For instance, sellers might sell 14-day cell phones (a prototype) as brand new ones at extremely low prices, but these phones would not work after the 7-day return guarantee expires.

The prevalence of abnormal price dispersion in C2C market undermines the market efficiency in two ways. First, experienced buyers might perceive high risk and spend much effort to identify trustworthy sellers, and amateur buyers might be easily misled by low price signals and would hardly build sufficient trust to engage in further transaction. Second, according to the Range Theory (Janiszewski \& Lichtenstein, 1999), abnormal low/ high prices extend the range of the product price, and buyers might feel expensive/cheap when they see the fair prices. Therefore, the abnormal price dispersion could disturb the buyers' perception of fair product prices and cause them to spend more time and effort to search for price information.

\subsection{Perceived risk}

Perceived risk is defined as a subjective possible loss when pursuing a desired result (Nepomuceno et al., 2014). It has been categorized into at least seven different types (see Table 2) (Lim, 2003; Martins et al., 2014). 


\section{Insert Table 2 Here}

Considerable research has been done to study perceived risk. For example, Kim, et al. (2008) considers the influence of different aspects of website design (e.g., presence of third-party seal, information quality) on perceived risk. And Ko, et al. (2004) evaluate differences in perceived risk between online shoppers and nononline shoppers in multi-culture context.

However, existing research on perceived risk in C2C context is limited, while C2C purchase has various characteristics that need to be addressed. Verhagen, et al. (2006) suggest that in C2C purchase, buyers need to face the risks that come from both intermediary and seller. $\mathrm{Xu}$, et al. (2010) also argue that C2C buyers face higher risk due to the physical separation and an uncertainty about sellers’ profiles. Chung (2013) points out that perceived risk is likely to mediate the effect of price dispersion on attitude when buyers are concerned about the causes of different prices quotes for a product. Yet, none of the current studies explores how potential buyers perceive risks when dealing with a set of sellers with varied prices.

\subsection{Initial Trust}

Trust is generally described as a willingness of a party to be vulnerable to the actions of another party (Park et al., 2012). In this study, we are interested in the initialization of trust when buyers do not have any experience with sellers. Specifically, following Pavlou \& Gefen’s (2004) work, we limit the scope of initial trust to “trust towards a set of unfamiliar sellers who are listed in the result page of product search”. In C2C purchase, trust towards a set of unfamiliar sellers is important since it helps buyers to formulate a general belief of whether a certain set of sellers in general is committed to the appropriate rules of conducting transaction (Pavlou \& Gefen, 2004).

Previous e-commerce studies usually incorporate initial trust with the constructs in the technology acceptance model (TAM) (Hampton-Sosa \& Koufaris, 2005; Kim, 2012), while the interaction of initial trust with other variables (e.g., price dispersion, perceived value) has not been thoroughly studied. Moreover, few studies have focused on the relationship between trust and perceived risk in C2C context, and the casual relationships between perceived risk and trust have not gained general consensus.

Five kinds of relationships have been found in the literature. First, trust and perceived risk are used as independent variables (Verhagen, et al., 2006). Second, perceived risk acts as a moderator and decreases the positive relation between trust and purchase intention (Stewart, 1999). Third, trust negatively precedes perceived risk (Kim, et al., 2008; Pavlou, 2003). Forth, the relationship between these two factors is reciprocal (Chang \& 
Chen, 2008). Finally, perceived risk negatively influences trust (Chen \& Chang, 2012; Corbitt et al., 2003).

\subsection{Perceived value}

One of the key links between cognitive elements (e.g., perceived risk, cognitive trust, and perceived quality) and purchase intention is value. Customers are usually "value-driven”, therefore how a customer values the product or service is crucial for both businesses and researchers (Sweeney \& Soutar, 2001). Perceived value is defined as a trade-off between the benefit and the cost perceived by the customer (Forsythe et al., 2006; Kim, et al., 2012). This concept is different from the concept of satisfaction since the former occurs during all the stages of the purchase process, whilst the latter depends on the experience of using or consuming the good or service. Furthermore, perceived value is also different from perceived price, as perceived value is a complementary variable containing emotional, social and functional assessments (Sweeney \& Soutar, 2001).

Several studies have discussed the concept of perceived value in both the pre-purchase and post-purchase stages. Customer's perception of value can be positively influenced by product/service quality, seller image and price, and negatively influenced by perceived risk and costs (Agarwal \& Teas, 2001; Chang \& Tseng, 2011). Perceived value can further facilitate loyalty, and influence customer's post-purchase intention directly or indirectly (e.g., satisfaction as a mediator) (Kuo et al., 2009; Tam, 2004; Wang, 2010).

In this research, we use perceived value as a mediator of the effect of cognitive variables (trust, perceived risk, price dispersion) on purchase intention. The influences of trust and perceived risk on perceived value have been addressed in previous studies (Agarwal \& Teas, 2001; Kim, 2012). However, how price dispersion influences the perceived value has remained to be addressed.

\section{Research Hypotheses}

The utility theory suggests that buyers are economically rational and they will try to maximize utility or satisfaction during transactions (Chen \& Dubinsky, 2003). Perceived value reflects buyers’ net gain obtained from their purchases, which is a difference between their overall calculation of gains (e.g., usefulness of product, satisfaction) and their losses (e.g., monetary loss, discomfort with confusing prices, search effort, risk) in transactions (Forsythe, et al., 2006; Kim, et al., 2012). The higher net gain buyers expect to receive, the stronger the purchase intention of buyers. The close relationship between perceived value and purchase intention has been supported in previous studies (Chen \& Dubinsky, 2003; Kim, et al., 2012). Therefore, we hypothesize that: 
H1: perceived value has a positive influence on purchase intention.

Price dispersion increases buyers’ price sensitivity (Pan, et al., 2004). High levels of price dispersion motivate buyers to execute more search activities and examine differences among alternatives in order to locate the most suitable product. Previous studies have found the positive effect of price dispersion on search intention (Biswas \& Burman, 2009; Caglayan et al., 2008). As buyers spend more time and effort on the transaction, the cost of transaction increases and the perceived value decreases. Therefore, we hypothesize that:

H2: price dispersion has a negative influence on perceived value.

Price dispersion also increases the uncertainty of transaction (Biswas et al., 2006). Buyers might be skeptical of the products with irregular low/high prices. For a given product, a low price is usually attributed to fraud, low quality, poor warranty, or a way to gather private information (Kirmani \& Rao, 2000; Miyazaki et al., 2005; Zhang, et al., 2012). For instance, a low quality product may cause various problems during usage and lead to higher performance risk (e.g., not working), social risk (e.g., blamed by friends), time risk (e.g., waiting for replacement) and physical risk (e.g. leakage of electricity). On the other hand, high price sellers could also be suspicious of taking advantage of information asymmetry (Akerlof, 1970; Biswas, et al., 2006). They might over-emphasize some unnecessary characteristics of the product or service to enjoy price premium (the buyer may feel regretful after purchase); make the best claims but deliver regular product or service (may lead to performance and financial risk); or execute fraud activities which are more profitable in high-priced products than in low-priced ones (may lead to financial risk). As a result, buyers' perceived risk increases. Examples of the transaction risk when purchasing either high-priced or low-priced products have been reported in many studies (Chua et al., 2007; Zhang, et al., 2012). Therefore, we hypothesize that:

H3: price dispersion has a positive influence on perceived risk.

Risks are indicators of future potential costs, but buyers usually take prospective cost or benefits into consideration when they perceive present costs or benefits (Agarwal \& Teas, 2001). Thus, it is reasonable to argue that buyers would consider risks (e.g., a high probability of product replacement after purchase) when they assess product value. The negative influence of perceived risk on perceived value is supported in previous studies (Agarwal \& Teas, 2001; Chen \& Dubinsky, 2003). Therefore, we hypothesize that:

H4: perceived risk has a negative influence on perceived value. 
Perceived risk can affect customers’ purchase decision process - consumers usually seek for solutions to minimize their perceived risk (Mitchell, 1999). However, the information asymmetry makes it difficult for buyers to judge product value, and instead, provides sellers with the opportunity to act fraudulently (Mishra et al., 1998). Thus, buyers might be reluctant to trust the product if they perceive high risk (Mitchell, 1999). Moreover, perceived risk is closely related to negative consumption emotions, such as fear and disgust (Chaudhuri, 1997), which could undermine trust building (Dunn \& Schweitzer, 2005). The negative influence of perceived risk on trust is supported in previous studies (Eid, 2011). Therefore, we hypothesize that:

H5: perceived risk has a negative influence on initial trust.

Trust can reduce the time and effort that buyers should dedicate to select a suitable seller (Chiles \& Mcmackin, 1996). Once initial trust is built, buyers tend to spend less effort to accomplish transactions with the seller (Kim, et al., 2012). Thus, buyers’ perceived value increases. The positive relationship between trust and perceived value has been supported in many studies (Chen \& Chang, 2012; Chiou, 2004; Kim, et al., 2012). Moreover, trust literature supports a direct relationship between trust and purchase intention (Pavlou, 2003). Therefore, we hypothesize that:

H6: initial trust has a positive influence on perceived value.

H7: initial trust has a positive influence on purchase intention.

The concept of "low-touch" and "high-touch" is closely related to uncertainty (Weathers et al., 2007). The attributes of "low-touch" products can be known prior to purchase, while the attributes of "high-touch" products are difficult to judge and can only be known through direct experiences (Chiang \& Dholakia, 2003). Therefore, price becomes an important signal of quality for buyers (Hsieh et al., 2005; Kalita et al., 2004). However, sellers with “high-touch” products can take advantage of buyers’ lack of information about products' attributes and apply various prices. Such activities would lead to a wide range of price distribution (high level of price dispersion), making it more challenging for buyers to assess the product value. On the contrary, in case "hightouch” products have a low level of price dispersion, the search cost of buyers would be reduced as they are able to evaluate the quality of product along with the product value more confidently. Therefore, we hypothesize that: H8: The negative effect of price dispersion on perceived value will be stronger in the purchase of "high- touch" product than that in the purchase of "low-touch" product. 
H9: The positive effect of price dispersion on perceived risk will be stronger in the purchase of "high- touch" product than that in the purchase of "low-touch" product.

\section{Research methodology}

We choose a survey-based lab experiment for this study due to the two reasons: 1) a survey method is usually preferred when a research requires perceptual data (Gao \& Bai, 2014); and 2) a lab experiment provides an accessible way to compare buyers’ perceptions across different product types.

\subsection{Selection of product categories}

Motivated by previous studies on price dispersion (Brynjolfsson \& Smith, 2000; Kim, et al., 2012; Lu et al., 2007), we select books and CDs as low-touch goods as their characteristics are more identical and stable. For high-touch products, we choose cell phones and clothes as their features (e.g., the sensitivity of screen) cannot be thoroughly known before purchase. Our selection is in accordance with previous studies (Girard et al., 2003).

\subsection{Preparation of experiment data}

Taobao is selected as the target C2C platform to obtain experiment data. This platform is chosen because, first, it occupies an absolute leading position among all C2C platforms, it had more sales than Amazon and eBay combined in 2013 (Popper, 2014). Second, it is well-known in Chinese communities, and it is usually considered as a typical C2C sample in previous studies. Third, although the issues of reputation manipulation and product quality may force customers to choose other retail channels, a recent official report indicates that still more than 70\% online buyers choose Taobao as their primary choice (Cnnic, 2014).

We have developed a crawler to download product information (e.g., titles, prices and sellers' information) from Taobao in March 2014. We gathered 400 product titles, in which every 100 titles belong to one of the four product categories (books, CDs, cell phones and clothes). These titles of products are selected from Taobao's best-selling list. Note that all products in our system were claimed to be brand new ones because Taobao lists only brand new products in the search results by default.

We built a prototype system similar to Taobao to conduct the experiment. The product information (picture and description), price distribution, and sellers' information (name and location) were exactly the same as those in the real market. However, we discarded the information about sales volume, reputation and service guarantee 
to reduce the potential influences of social influence, reputation and service guarantee. A screenshot of the system is shown in Figure 1.

\section{Insert Figure 1 Here}

\subsection{Description of experiment}

Before the experiment, participants were told to imagine that they were shopping in Taobao to purchase a gift from selected categories (book/CD/cell phone/clothes) for an important person. They were allocated adequate amount of money to make purchase, and they needed to form a general feeling about potential risks and trust towards a list of sellers based on the offered prices.

Then we randomly divided participants into two equal-sized groups: 1) participants who would purchase low-touch products and 2) participants who would purchase high-touch products. In the first group, half of the participants were assigned to purchase books and the rest were assigned to purchase CDs. In the other group, half of the participants were assigned to purchase cell phones and the rest were assigned to purchase clothes. We provided five product alternatives to every participant (e.g. a participant who was assigned to purchase a cell phone received five different cell phone items) and required them to choose one as their target product. Participants were asked to select a product that they don't have any prior purchase experience (self-reported by participants), because previous experience with the product can potentially influence perceived risk. For example, a participant who previously purchased an item may know how price signals the quality of this item. Besides, since we focus on how buyers generate initial trust, participants who performed as "new buyers” were preferred.

Once a product was selected, the participant clicked a button named "Ready to go" and he/she would receive a list of sellers with different price quotes (Figure 1). The order of price quotes in the list was randomly assigned. And each list contains 48 price quotes per page (same as Taobao). Then the participant had 5 to 20 minutes to form attitude towards these sellers (e.g., analysis the causes of price dispersion, intention to conduct transaction with one of these sellers), depending on his/her speed of judgement. Once the participant finished reviewing the information, he/she clicked a button named "Finish" to be redirected to a survey page, where an electronic questionnaire has been provided. The filling of questionnaires was controlled by a software program which did not allow missing selections.

\subsection{Participants}


We made an open invitation through in-campus bulletin board system (BBS) and posters to students in a Chinese university. We required that each participant should have C2C purchase experience. To encourage participation, we announced in the invitation that each participant who provided valid feedback would receive USD\$ 1.6 (CNY $¥ 10$ ) as a reward for the time spent in the experiment. We stopped accepting new participants when the number of applicants reached 300. The participants were largely undergraduates since the campus where we made invitation was mainly used for teaching undergraduates. 272 students participated in our experiment and 261 valid responses were finally gathered (valid rate: 96\%).

The demographic information of participants were listed in Table 3. This sample is suitable since previous studies report that young adults and university students are a typical groups of online consumers. Similar sampling approach has been employed in previous trust and online shopping literature (Kim, et al., 2008). Moreover, a recent official survey shows that $56.4 \%$ of Chinese C2C buyers are aged between 20 and 29, 35.9\% of buyers have (or are pursuing for) bachelor degree, and the percentages of male and female buyers are by and large equal (Cnnic, 2014).

\section{Insert Table 3 Here}

\subsection{Instrument development}

Table 4 shows the details of measurable items. We translated these items into Chinese with the assistance of a professor from department of language studies. Two Ph.D students major in information system also reviewed the translated content. Three items were designed to measure Initial trust towards a set of sellers. In line with previous studies (Kim, et al., 2008; Luo et al., 2010), perceived risk was modelled as a formative latent construct with seven items, which reflect seven types of perceived risk respectively. A formative representation of perceived risk is preferred because an increase in one type of risk (e.g., performance risk) may not cause an increase in other types of perceived risks (e.g., financial risk). As a result, changes in one indicator influence the formative construct (perceived risk); yet, a change in the construct not necessarily impacts all its observed items (Andreev et al., 2009). The four measurement items of purchase intention were used to measure buyers' intention to purchase from the list of sellers. We have done small modifications on each item to fit online C2C context. We consider factors such as age, gender, and C2C purchase experience as control variables. 


\section{Insert Table 4 Here}

\section{Data Analysis}

Since we have one formative construct, we select Partial Least Squares (PLS) to test the proposed model, as suggested by previous study (Kim, et al., 2008). Moreover, PLS is a suitable analaysis method when the distribution of sample does not follow multivariate normality (Kallweit et al., 2014).We used WarpPLS 4.0 with classic PLS algroithm and bootstrapping.

\subsection{Measurement Model}

In PLS analysis, the measurement model is tested by examining: individual item reliability, internal consistency, and discriminate validity (Yoo \& Alavi, 2001). The result of measurement model test is shown in Table 5.

For individual item reliability, the factor loading of about 0.7 or greater is desired, whereas the value below 0.5 shows low trait variance (Bagozzi, 2011). Table 5 shows all factor loadings exceed 0.5. The composite reliability and the Cronbach’s alpha are both used for evaluating the internal consistency of the constructs, and 0.7 is the recommended threshold (Bagozzi, 2011). It can be seen from Table 5 that all constructs have met this criterion. All AVEs shown in Table 5 are greater than the recommended value (0.5), suggesting that the latent constructs account for the majority of the variance in their indicators on average (Mackenzie et al., 2011). Moreover, Table 6 shows that the square roots of AVEs are all larger than corresponding correlations, and Table 5 suggests that no measurement items load more highly on a construct other than the construct it intends to measure (Yoo \& Alavi, 2001). Thus, discriminate validity is observed.

We further examined the issue of multi-collinearity by following Ke and Zhang's (2010) suggestion. The result indicates that multi-collinearity is not a serious issue in our dataset because the highest variance inflation factor (VIF) is only 2.501. Then we tested the common method bias by performing Harman's one-factor test (Podsakoff et al., 2003), the result shows that no single factor accounts for most of the variance and therefore no significant common method bias in our dataset.

\section{Insert Table 5 and Table 6 Here}

\subsection{Structural Model}


We considered age, gender and purchase experience as control variables with a full sample size. Results show that p values for these variables are $0.385,0.398,0.489$, respectively. Therefore, no significant effects of control variables were found.

In the test for structural model, ten fitness indices are provided in WarpPLS. The results shown in Table 7 suggest that our proposed model has good model fitness.

\section{Insert Table 5 and Figure 2 Here}

Figure 2 shows the result of the structural model. The results suggest that perceived value positively influences purchase intention $(\beta=0.35, \mathrm{~S} . \mathrm{E}=0.064)$, therefore, $\mathrm{H} 1$ is supported. Price dispersion is found to negatively influence perceived value $(\beta=-0.21, \mathrm{~S} . \mathrm{E}=0.063)$, it also positively influences perceived risk $(\beta=0.68$, S.E=0.035). Thus, both H2 and H3 are supported. Perceived risk has negative impacts on both perceived value ( $\beta=-0.16$, S. $E=0.082)$ and initial trust $(\beta=-0.60, \mathrm{~S} . \mathrm{E}=0.041)$, therefore, both $\mathrm{H} 4$ and $\mathrm{H} 5$ are supported. The results further show that, initial trust has significant positive effects on both perceived value $(\beta=0.39$, S.E=0.079) and purchase intention $(\beta=0.42$, S.E=0.060). Thus, H6 and H7 are supported. The percentage of the variance explained $\left(\mathrm{R}^{2}\right)$ of initial trust, perceived risk, perceived value and purchase intention are 37\%, 47\%, 42\%, and 47\%, respectively. Moreover, we use $\mathrm{Q}^{2}$ coefficient (Geisser, 1975) to serve as a resampling analog of the $\mathrm{R}^{2}$ coefficient to address one shortcoming of $\mathrm{R}^{2}$ : the same data that is used to build the equation is also used to evaluate it. The $\mathrm{Q}^{2}$ values of initial trust, perceived risk, perceived value and purchase intention are $0.37,0.46$, 0.42, and 0.47, respectively. The similar values of $\mathrm{R}^{2}$ and $\mathrm{Q}^{2}$ confirm the predictability of our model.

The moderating effect of product type (see Figure 3) is evaluated by following the procedure suggested by Keil et al (2000). We found that the path coefficient from price dispersion to perceived risk in the structural model for the "high-touch" product group $(\beta=0.71$, S.E. $=0.051)$ is significantly stronger than that for the "lowtouch" product group $(\beta=0.60$, S.E. $=0.053)(\mathrm{t}=-17.088, \mathrm{p}<0.001)$. Meanwhile, the negative effect of price dispersion on perceived value is stronger in the "high-touch" product group $(\beta=-0.33$, S.E.=0.081) than that in the "low-touch" product group $(\beta=-0.18$, S.E.=0.100) $(\mathrm{t}=13.34, \mathrm{p}<0.001)$. Thus, H8 and H9 are supported.

\section{Insert Figure 3 Here}

\section{Discussion, Implication and Limitation}


In C2C market, many factors contribute to different pricing of a given product. Due to information asymmetry, buyers can only evaluate target product or seller based on available information cues. In the absence of reliable reputation mechanisms in Chinese $\mathrm{C} 2 \mathrm{C}$ market, it is reasonable to expect that price-related information becomes more important to support buyers' judgement. In this study, we use attribution theory as a theoretical basis and try to understand how $\mathrm{C} 2 \mathrm{C}$ buyers analyze the causes of price dispersion when they receive a list of price quotes.

\subsection{Discussion of Findings}

Our results firstly show that price dispersion has a direct negative influence on perceived value, while previous studies paid no attention to this relationship. High levels of price dispersion can motivate buyers to dedicate more search effort to locate the best offer, as indicated by the Economics of Information theory (Biswas \& Burman, 2009). This search effort may not be caused by perceived risk (e.g., buyers feel risks and need to find a product with good service guarantee), but be caused by the need of comparing prices in order to achieve a specific amount of price savings, as suggested by the Transaction Utility Theory (Grewal \& Marmorstein, 1994).

Moreover, our results also show that price dispersion can positively affect perceived risk, which further negatively influences buyers’ perceived value. High levels of price dispersion often happen when there is a wide range of sellers whose service/product quality and levels of trustworthiness are varied. Especially, in C2C market, product or service quality is usually differed in terms of warranty (e.g., 1 month or 1 year, seller warranty or official warranty), after-sale service (e.g., 7-day or 14-day return without excuse), payment (e.g., whether credit card is supported), speed of refund (e.g., refund instantly or within 7 days) and batches of product (e.g., electronics produced in the first batch have a higher defect rate due to the development of maturity), etc. Therefore, buyers may feel potential risks and are motivated to dedicate more time and effort to reduce their uncertainty (e.g., to discover whether there are different warranty periods among sellers). As a result, buyers' search cost increased and their net gains from transaction decreased.

Regarding the impact of price dispersion on initial trust, our results show that price dispersion has a negative influence on initial trust, and perceived risk acts as a mediator. Our model does not assume a direct influence of price dispersion on initial trust since price dispersion cannot directly lead to decreased trust. For a given product, although it has high level of price dispersion, buyers would feel confident if sellers honestly mention the reasons of their different pricing. Instead, we suggest that perceived risk should be a mediator, which is closer to the real-world scenarios in C2C market, where a large amount of sellers are deceitful and 
intentionally hide their critical transaction information (e.g., product quality). In this case, price dispersion positively influences perceived risk, which then negatively influences initial trust.

Initial trust is found to positively influence perceived value. If buyers have high initial trust towards a community of sellers, they would be more inclined to believe that these sellers' prices reflect their actual product/service quality. As a result, buyers spend less time and effort to select target price (seller) and their perceived value increases.

Finally, our results show that product type moderates the consequences of price dispersion. The negative effects of price dispersion on perceived value and the positive effects of price dispersion on perceived risk become stronger when buyers purchase high-touch products. We attribute this finding to the lack of information to help buyers to make judgement, because buyers need more information when they buy high-touch products than low-touch ones. Our finding confirms the results of previous study, which finds that higher search effort are needed for high-touch product (Huang et al., 2009).

\subsection{Implications for literature}

Our study yields several implications for research on price dispersion, trust and risk. First, little attention has been paid in the literature to study the effect of price dispersion in C2C context. Our model suggests that price dispersion negatively affect buyers in two ways: 1) it increases buyers’ perceived risk, and 2) it requires buyers to put more effort to locate the best offer and therefore reduces perceived value. Second, previous studies have investigated the effects of trust on price dispersion, i.e., a seller with higher trust value enjoys a higher price premium (Brynjolfsson \& Smith, 2000; Pan, et al., 2004); however, it is unknown that how price dispersion influences trust. Our results show that price dispersion negatively affects initial trust, as it increases uncertainty and therefore induces buyers to form negative attitude towards a set of sellers, despite the existence of honest sellers. Third, both business surveys and literature suggest that the ratio of the repeated purchase in C2C market is not high (Ke, 2012; Pavlou \& Gefen, 2004). Therefore, C2C sellers should be sufficiently attractive to stimulate initial trust of new buyers. Our study focuses on initial trust toward a set of sellers, which has been mostly neglected in previous studies. Fourth, high-touch products provide better opportunities for dishonest sellers to engage in fraudulent activities, thus the level of price dispersion among high-touch products is higher than that among low-touch products. We found that price dispersion has stronger negative impact in high-touch products, while few study has addressed this moderating effect. 


\subsection{Implications for practice}

Our study also provides several practical implications. First, our findings are useful for C2C sellers to design pricing strategy. Although prices are mainly determined by cost, how to price a product is also important. Both low-priced and high-priced products might sound suspicious to buyers. Therefore, pricing low might not be a good choice for sellers who truthfully enjoy a lower-than-average product cost, because they could be misjudged to be untrustworthy. This case is very common since many Chinese C2C sellers are actually sale agents of factories, and they own cost advantages through direct sale. Second, our study sheds a light on the design of mechanisms to support purchase decision. Existing reputation systems adopted by e-commerce platforms only consider the transaction history between buyers and sellers (Gorner et al., 2013). Incorporating price dispersion can be helpful to address the "cold-start" problem when there are no transaction history and reputation information available. Third, our study offers a new way for C2C platforms to design prime services. Currently, sellers have to pay service fee to sort their products in the top positions. As a further step, platforms can develop new mechanisms to manage the result list and position the target product in a list of reasonably priced products, because trust towards the list determines buyer's willingness to choose an alternative from the list.

\subsection{Limitation and future work}

This study has a couple of limitations, which affect the generalizability of our findings. First, our findings cannot explain C2C buyers who do not have much purchase experience. Price dispersion is a heuristic cue in online shopping context (Chung, 2013), therefore how buyers attribute the causes of price dispersion depends on their own characteristics (e.g., involvement, knowledge, experience). Intuition suggests that inexperienced buyers are more confused when facing products with high price dispersion, as they are not aware of the overall trustworthiness of sellers in the market. Therefore, they need to spend more time and effort to search suitable products. In this regard, our model may still be predictive. Yet, for those buyers with low cognitive ability (e.g., older customers), the predictability of our model is unknown. This is because these customers are usually unable to perceive risk, and also it is difficult for them to form an attitude through extra search efforts. In future work we will extend our study to incorporate various types of customers in our model (e.g., non-shoppers).

Second, we did not consider the issue of product obsolescence. Unlike eBay, which clearly mentions product condition (e.g., brand new or used) along with the product information, Taobao only list brand new products by default. Product age can increase buyer's uncertainty towards the product quality; meanwhile, the 
relative low price of used product increases the level of price dispersion, make it difficult for buyers to perceive fair product price. Buyers would perceive high risk (e.g., regarding product quality, after-sale service) to conduct a transaction, and need to spend more search effort to reduce uncertainty. Therefore, it is reasonable to assume that our research model is predictive when taking product age into consideration.

Third, although empirical data well support our model, a possible avenue for future work would be to explore the predictability of alternative models. For instance, we have proposed that both price dispersion and perceived risk influence purchase intention via their effects on perceived value. However, previous studies suggest a direct influence of perceived risk on purchase intention (Kim, et al., 2008; Ratchford, 2009). Besides, since many types of relationships have been proposed between perceived risk and trust, it is valuable to explore how trust influences perceived risk under different levels of price dispersion.

\section{References}

Agarwal, S., \& Teas, R. K. (2001). Perceived value: Mediating role of perceived risk. Journal of Marketing theory and Practice, 1-14.

Akerlof, G. A. (1970). The market for "lemons": Quality uncertainty and the market mechanism. The Quarterly Journal of Economics, 84(3), 488-500.

Ancarani, F., \& Shankar, V. (2004). Price levels and price dispersion within and across multiple retailer types: Further evidence and extension. Journal of the Academy of Marketing Science, 32(2), 176-187.

Andreev, P., Heart, T., Maoz, H., \& Pliskin, N. (2009). Validating formative partial least squares (pls) models: Methodological review and empirical illustration. Paper presented at the ICIS 2009 Proceedings.

Ba, S., \& Pavlou, P. A. (2002). Evidence of the effect of trust building technology in electronic markets: Price premiums and buyer behavior. MIS Quarterly, 243-268.

Bagozzi, R. P. (2011). Measurement and meaning in information systems and organizational research: Methodological and philosophical foundations. MIS Quarterly, 35(2), 261-292.

Baylis, K., \& Perloff, J. M. (2002). Price dispersion on the internet: Good firms, bad firms. Review of Industrial Organization, 21(3), 305-324.

Biswas, A., Dutta, S., \& Pullig, C. (2006). Low price guarantees as signals of lowest price: The moderating role of perceived price dispersion. Journal of Retailing, 82(3), 245-257.

Biswas, D. (2004). Economics of information in the web economy: Towards a new theory? Journal of Business Research, 57(7), 724-733.

Biswas, D., \& Burman, B. (2009). The effects of product digitalization and price dispersion on search intentions in offline versus online settings: The mediating effects of perceived risks. Journal of Product \& Brand Management, 18(7), 477-486.

Bock, G.-W., Lee, S.-Y. T., \& Li, H. Y. (2007). Price comparison and price dispersion: Products and retailers at different internet maturity stages. International Journal of Electronic Commerce, 11(4), 101-124.

Brown, J. R., \& Goolsbee, A. (2002). Does the internet make markets more competitive? Evidence from the life insurance industry. Journal of Political Economy, 110(3), 481-507.

Brynjolfsson, E., \& Smith, M. D. (2000). Frictionless commerce? A comparison of internet and conventional retailers. Management Science, 46(4), 563-585.

Caglayan, M., Filiztekin, A., \& Rauh, M. T. (2008). Inflation, price dispersion, and market structure. European Economic Review, 52(7), 1187-1208.

Chang, E.-C., \& Tseng, Y.-F. (2011). Research note: E-store image, perceived value and perceived risk. Journal of Business Research.

Chang, H. H., \& Chen, S. W. (2008). The impact of online store environment cues on purchase intention: Trust and perceived risk as a mediator. Online Information Review, 32(6), 818-841.

Chang, M.-L., \& Wu, W.-Y. (2012). Revisiting perceived risk in the context of online shopping: An alternative perspective of decision-making styles. Psychology \& Marketing, 29(5), 378-400. 
Chaudhuri, A. (1997). Consumption emotion and perceived risk: A macro-analytic approach. Journal of Business Research, 39(2), 81-92.

Chellappa, R. K., Sin, R. G., \& Siddarth, S. (2011). Price formats as a source of price dispersion: A study of online and offline prices in the domestic us airline markets. Information Systems Research, 22(1), 83-98.

Chen, E. Y., \& Bei, L.-T. (2005). The effects of price dispersion and suggested list price on consumers' internal reference price. Consumer Interests Annual, 51, 160-170.

Chen, Y.-S., \& Chang, C.-H. (2012). Enhance green purchase intentions: The roles of green perceived value, green perceived risk, and green trust. Management Decision, 50(3), 502-520.

Chen, Z., \& Dubinsky, A. J. (2003). A conceptual model of perceived customer value in e-commerce: A preliminary investigation. Psychology and Marketing, 20(4), 323-347.

Chiang, K.-P., \& Dholakia, R. R. (2003). Factors driving consumer intention to shop online: An empirical investigation. Journal of Consumer Psychology, 13(1-2), 177-183.

Chiles, T. H., \& McMackin, J. F. (1996). Integrating variable risk preferences, trust, and transaction cost economics. Academy of Management Review, 21(1), 73-99.

Chiou, J.-S. (2004). The antecedents of consumers' loyalty toward internet service providers. Information \& Management, 41(6), 685-695.

Chua, C. E. H., Wareham, J., \& Robey, D. (2007). The role of online trading communities in managing internet auction fraud. MIS Quarterly, 31(4), 759-781.

Chung, M., Moon, J., Yoo, B., \& Choe, Y. (2006). Paradox of information quality: Do consumers pay more for premium product information on e-commerce sites? AMCIS 2006 Proceedings, 57.

Chung, S. (2013). The role of online informediaries for consumers: A dual perspective about price comparison and information mediation. Internet Research, 23(3), 338-354.

Clay, K., Krishnan, R., Wolff, E., \& Fernandes, D. (2002). Retail strategies on the web: Price and non-price competition in the online book industry. The Journal of Industrial Economics, 50(3), 351-367.

Clemons, E. K., Hann, I.-H., \& Hitt, L. M. (2002). Price dispersion and differentiation in online travel: An empirical investigation. Management Science, 48(4), 534-549.

CNNIC. (2014). 2013 statistical report on chinese internet shopping Retrieved from https://www.cnnic.net.cn/hlwfzyj/hlwxzbg/dzswbg/201404/t20140421_46598.htm

Corbitt, B. J., Thanasankit, T., \& Yi, H. (2003). Trust and e-commerce: A study of consumer perceptions. Electronic Commerce Research and Applications, 2(3), 203-215.

Dunn, J. R., \& Schweitzer, M. E. (2005). Feeling and believing: The influence of emotion on trust. Journal of Personality and Social Psychology, 88(5), 736.

Eid, M. I. (2011). Determinants of e-commerce customer satisfaction, trust, and loyalty in saudi arabia. Journal of Electronic Commerce Research, 12(1), 78-93.

Forsythe, S., Liu, C., Shannon, D., \& Gardner, L. C. (2006). Development of a scale to measure the perceived benefits and risks of online shopping. Journal of Interactive Marketing, 20(2), 55-75.

Gao, L., \& Bai, X. (2014). Online consumer behaviour and its relationship to website atmospheric induced flow: Insights into online travel agencies in china. Journal of Retailing and Consumer Services, 21(4), 653-665.

Geisser, S. (1975). The predictive sample reuse method with applications. Journal of the American Statistical Association, 70(350), 320-328.

Ghose, A., Mukhopadhyay, T., \& Rajan, U. (2007). The impact of internet referral services on a supply chain. Information Systems Research, 18(3), 300-319.

Ghose, A., \& Yao, Y. (2011). Using transaction prices to re-examine price dispersion in electronic markets. Information Systems Research, 22(2), 269-288.

Girard, T., Korgaonkar, P., \& Silverblatt, R. (2003). Relationship of type of product, shopping orientations, and demographics with preference for shopping on the internet. Journal of Business and Psychology, 18(1), 101120.

Gorner, J., Zhang, J., \& Cohen, R. (2013). Improving trust modeling through the limit of advisor network size and use of referrals. Electronic Commerce Research and Applications, 12(2), 112-123.

Grewal, D., \& Marmorstein, H. (1994). Market price variation, perceived price variation, and consumers' price search decisions for durable goods. Journal of Consumer Research, 21(3), 453-460.

Hampton-Sosa, W., \& Koufaris, M. (2005). The effect of web site perceptions on initial trust in the owner company. International Journal of Electronic Commerce, 10(1), 55-81.

Han, H., \& Ryu, K. (2009). The roles of the physical environment, price perception, and customer satisfaction in determining customer loyalty in the restaurant industry. Journal of Hospitality \& Tourism Research, 33(4), 487-510.

Heider, F. (2013). The psychology of interpersonal relations. New Jersey: Psychology Press.

Hsieh, M.-T., \& Tsao, W.-C. (2014). Reducing perceived online shopping risk to enhance loyalty: A website quality perspective. Journal of Risk Research, 17(2), 241-261.

Hsieh, Y.-C., Chiu, H.-C., \& Chiang, M.-Y. (2005). Maintaining a committed online customer: A study across searchexperience-credence products. Journal of Retailing, 81(1), 75-82.

Hu, X., Wu, G., Wu, Y., \& Zhang, H. (2010). The effects of web assurance seals on consumers' initial trust in an online vendor: A functional perspective. Decision Support Systems, 48(2), 407-418.

Huang, P., Lurie, N. H., \& Mitra, S. (2009). Searching for experience on the web: An empirical examination of consumer behavior for search and experience goods. Journal of Marketing, 73(2), 55-69.

iResearch. (2013). C2c is dead, taobao survives. Retrieved from http://column.iresearch.cn/u/dingdaoshi/657432.shtml 
Janiszewski, C., \& Lichtenstein, D. R. (1999). A range theory account of price perception. Journal of Consumer Research, 25(4), 353-368.

Jin, G. Z., \& Kato, A. (2006). Price, quality, and reputation: Evidence from an online field experiment. The RAND Journal of Economics, 37(4), 983-1004.

Kalita, J. K., Jagpal, S., \& Lehmann, D. R. (2004). Do high prices signal high quality? A theoretical model and empirical results. Journal of Product \& Brand Management, 13(4), 279-288.

Kallweit, K., Spreer, P., \& Toporowski, W. (2014). Why do customers use self-service information technologies in retail? The mediating effect of perceived service quality. Journal of Retailing and Consumer Services, 21(3), 268-276.

Kardes, Frank R., Maria Cronley, James Kellaris, \& Steven Posavac. (2004). The role of selective information processing in price-quality inference. Journal of Consumer Research, 31(2), 368-374.

Ke, B. (2012, 2012-05-16). Repeat purchase rate can not be underestimated. Retrieved from http://www.maijiakan.com/detail/analyse/20120522/42152.htm?spm=a1z2j.6999689.1995879213.29.0gECXs

Ke, W., \& Zhang, P. (2010). The effects of extrinsic motivations and satisfaction in open source software development. Journal of the Association for Information Systems, 11(12), 784-808.

Keil, M., Tan, B. C. Y., Wei, K.-K., Saarinen, T., Tuunainen, V., \& Wassenaar, A. (2000). A cross-cultural study on escalation of commitment behavior in software projects. MIS Quarterly, 24(2), 299-325.

Kim, D. J., Ferrin, D. L., \& Rao, H. R. (2008). A trust-based consumer decision-making model in electronic commerce: The role of trust, perceived risk, and their antecedents. Decision Support Systems, 44(2), 544-564.

Kim, H.-W., Xu, Y., \& Gupta, S. (2012). Which is more important in internet shopping, perceived price or trust? Electronic Commerce Research and Applications, 11(3), 241-252.

Kim, J. (2012). An empirical study on consumer first purchase intention in online shopping: Integrating initial trust and tam. Electronic Commerce Research, 12(2), 125-150.

Kirmani, A., \& Rao, A. R. (2000). No pain, no gain: A critical review of the literature on signaling unobservable product quality. Journal of Marketing, 64(2), 66-79.

Ko, H., Jung, J., Kim, J., \& Shim, S. W. (2004). Cross-cultural differences in perceived risk of online shopping. Journal of Interactive Advertising, 4(2), 20-29.

Kuo, Y.-F., Wu, C.-M., \& Deng, W.-J. (2009). The relationships among service quality, perceived value, customer satisfaction, and post-purchase intention in mobile value-added services. Computers in Human Behavior, 25(4), 887-896.

Lai, H., Doong, H.-S., \& Yang, C.-Y. (2006). The effect of price dispersion in an e-market on consumers' intentions to join group buying. Paper presented at the System Sciences, 2006. HICSS'06. Proceedings of the 39th Annual Hawaii International Conference on.

Levin, A. M., Levin, I. R., \& Heath, C. E. (2003). Product category dependent consumer preferences for online and offline shopping features and their influence on multi-channel retail alliances. Journal of Electronic Commerce Research, 4(3), 85-93.

Lim, N. (2003). Consumers' perceived risk: Sources versus consequences. Electronic Commerce Research and Applications, 2(3), 216-228.

Lu, Y., Zhou, T., \& Wang, B. (2007). A comparison of prices in electronic markets and traditional markets of china. Chinese Economy, 40(5), 67-83.

Luo, X., Li, H., Zhang, J., \& Shim, J. P. (2010). Examining multi-dimensional trust and multi-faceted risk in initial acceptance of emerging technologies: An empirical study of mobile banking services. Decision Support Systems, 49(2), 222-234.

MacKenzie, S. B., Podsakoff, P. M., \& Podsakoff, N. P. (2011). Construct measurement and validation procedures in mis and behavioral research: Integrating new and existing techniques. MIS Quarterly, 35(2), 293-A295.

Martins, C., Oliveira, T., \& Popovič, A. (2014). Understanding the internet banking adoption: A unified theory of acceptance and use of technology and perceived risk application. International Journal of Information Management, 34(1), 1-13.

Maxwell, S. M., Estelami, H., \& Petrescu, M. (2011). Online price dispersion - more than imperfect information. Journal of Product \& Brand Management, 20(7), 541-548.

Mishra, D. P., Heide, J. B., \& Cort, S. G. (1998). Information asymmetry and levels of agency relationships. Journal of Marketing Research, 277-295.

Mitchell, V.-W. (1999). Consumer perceived risk: Conceptualisations and models. European Journal of Marketing, 33(1/2), 163-195.

Miyazaki, A., D.,, Dhruv Grewal, \& Ronald C. Goodstein. (2005). The effect of multiple extrinsic cues on quality perceptions: A matter of consistency. Journal of Consumer Research, 32(1), 146-153.

Nepomuceno, M. V., Laroche, M., \& Richard, M.-O. (2014). How to reduce perceived risk when buying online: The interactions between intangibility, product knowledge, brand familiarity, privacy and security concerns. Journal of Retailing and Consumer Services, 21(4), 619-629.

Pan, X., Ratchford, B. T., \& Shankar, V. (2002). Can price dispersion in online markets be explained by differences in e-tailer service quality? Journal of the Academy of Marketing Science, 30(4), 433-445.

Pan, X., Ratchford, B. T., \& Shankar, V. (2003). The evolution of price dispersion in internet retail markets. Advances in Applied Microeconomics, 12, 85-105.

Pan, X., Ratchford, B. T., \& Shankar, V. (2004). Price dispersion on the internet: A review and directions for future research. Journal of Interactive Marketing, 18(4), 116-135. 
Park, J., Gunn, F., \& Han, S.-L. (2012). Multidimensional trust building in e-retailing: Cross-cultural differences in trust formation and implications for perceived risk. Journal of Retailing and Consumer Services, 19(3), 304312.

Pavlou, P. A. (2003). Consumer acceptance of electronic commerce: Integrating trust and risk with the technology acceptance model. International Journal of Electronic Commerce, 7(3), 101-134.

Pavlou, P. A., \& Gefen, D. (2004). Building effective online marketplaces with institution-based trust. Information Systems Research, 15(1), 37-59.

Podsakoff, P. M., MacKenzie, S. B., Lee, J.-Y., \& Podsakoff, N. P. (2003). Common method biases in behavioral research: A critical review of the literature and recommended remedies. Journal of Applied Psychology, 88(5), 879.

Popper, B. (2014). Alibaba has more sales than amazon and ebay combined, but will americans trust it? Retrieved from http://www.theverge.com/2014/5/7/5690596/meet-alibaba-the-ecommerce-giant-with-more-sales-thanamazon-and-ebay

Prieto, M., Caemmerer, B., \& Baltas, G. (2015). Using a hedonic price model to test prospect theory assertions: The asymmetrical and nonlinear effect of reliability on used car prices. Journal of Retailing and Consumer Services, 22(0), 206-212.

Ratchford, B. T. (2009). Consumer search and pricing. Handbook of Pricing Research in Marketing, 91.

Ratchford, B. T., Pan, X., \& Shankar, V. (2003). On the efficiency of internet markets for consumer goods. Journal of Public Policy \& Marketing, 22(1), 4-16.

Roest, H., \& Rindfleisch, A. (2010). The influence of quality cues and typicality cues on restaurant purchase intention. Journal of Retailing and Consumer Services, 17(1), 10-18.

SAIC. (2015). Results of the targeted monitoring towards online traded products the second half of the year 2014. Beijing: State Administration for Industry \& Commerce of the People's Republic of China.

Scholten, P., \& Smith, S. A. (2002). Price dispersion then and now: Evidence from retail and e-tail markets. Advances in Applied Microeconomics, 11, 63-88.

Stewart, K. J. (1999). Transference as a means of building trust in world wide web sites. Paper presented at the Proceedings of the 20th international conference on Information Systems, Charlotte, North Carolina, USA.

Sweeney, J. C., \& Soutar, G. N. (2001). Consumer perceived value: The development of a multiple item scale. Journal of Retailing, 77(2), 203-220.

Tam, J. L. (2004). Customer satisfaction, service quality and perceived value: An integrative model. Journal of Marketing Management, 20(7-8), 897-917.

Tang, F.-F., \& Xing, X. (2001). Will the growth of multi-channel retailing diminish the pricing efficiency of the web? Journal of Retailing, 77(3), 319-333.

Verhagen, T., Meents, S., \& Tan, Y.-H. (2006). Perceived risk and trust associated with purchasing at electronic marketplaces. European Journal of Information Systems, 15(6), 542-555.

Walter, Z., Gupta, A., \& Su, B.-C. (2006). The sources of on-line price dispersion across product types: An integrative view of on-line search costs and price premiums. International Journal of Electronic Commerce, 11(1), 37-62.

Wang, C. (2010). Service quality, perceived value, corporate image, and customer loyalty in the context of varying levels of switching costs. Psychology \& Marketing, 27(3), 252-262.

Weathers, D., Sharma, S., \& Wood, S. L. (2007). Effects of online communication practices on consumer perceptions of performance uncertainty for search and experience goods. Journal of Retailing, 83(4), 393-401.

Xing, X., Yang, Z., \& Tang, F. F. (2006). A comparison of time-varying online price and price dispersion between multichannel and dotcom dvd retailers. Journal of Interactive Marketing, 20(2), 3-20.

Xu, B., Lin, Z., \& Shao, B. (2010). Factors affecting consumer behaviors in online buy-it-now auctions. Internet Research, 20(5), 509-526.

Yoo, Y., \& Alavi, M. (2001). Media and group cohesion: Relative influences on social presence, task participation, and group consensus. MIS Quarterly, 25(3), 371-390.

Zhang, Y., Bian, J., \& Zhu, W. (2012). Trust fraud: A crucial challenge for china's e-commerce market. Electronic Commerce Research and Applications, 12(5), 299-308. 


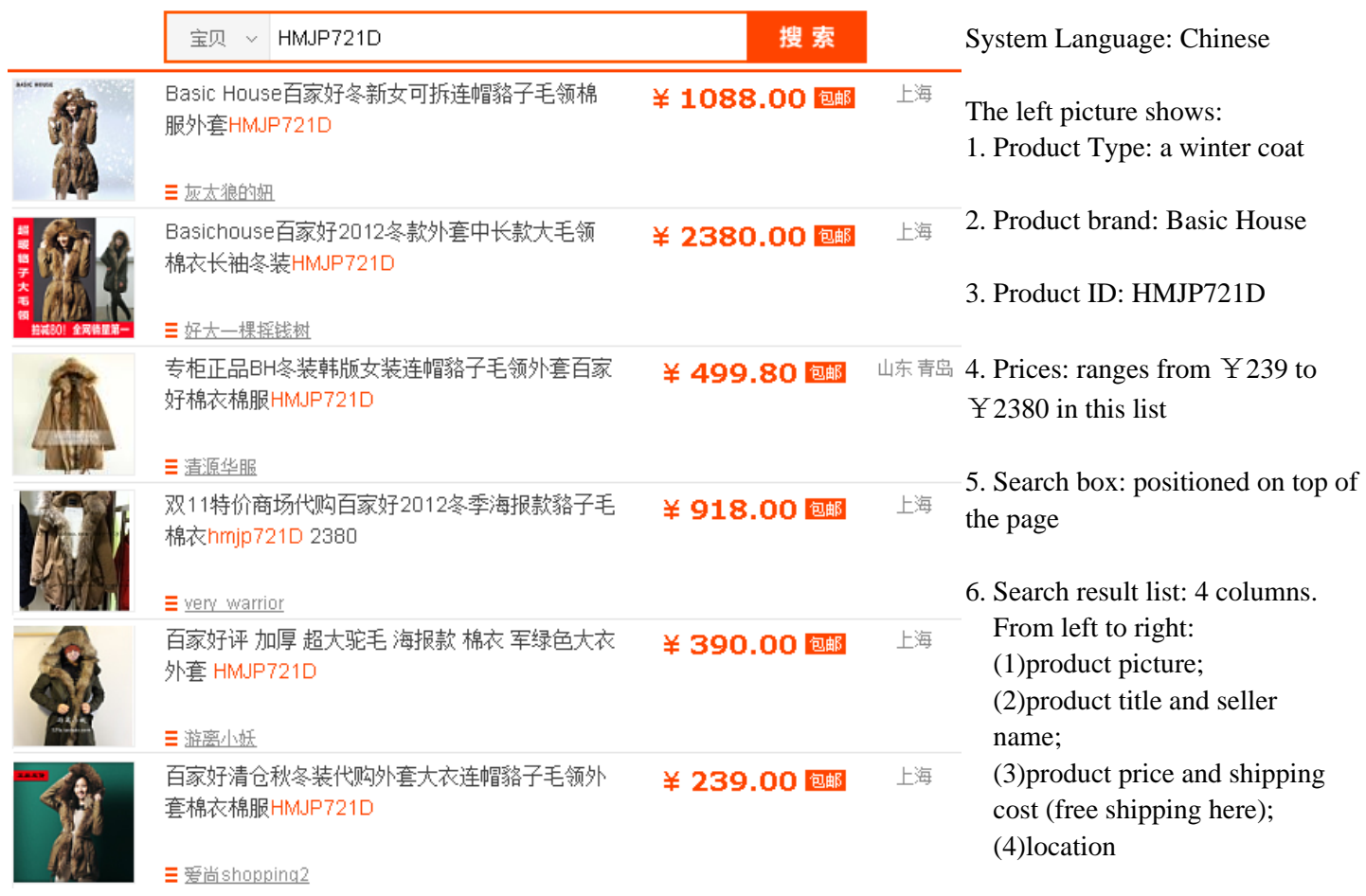

Figure 1 A screenshot of experimental system

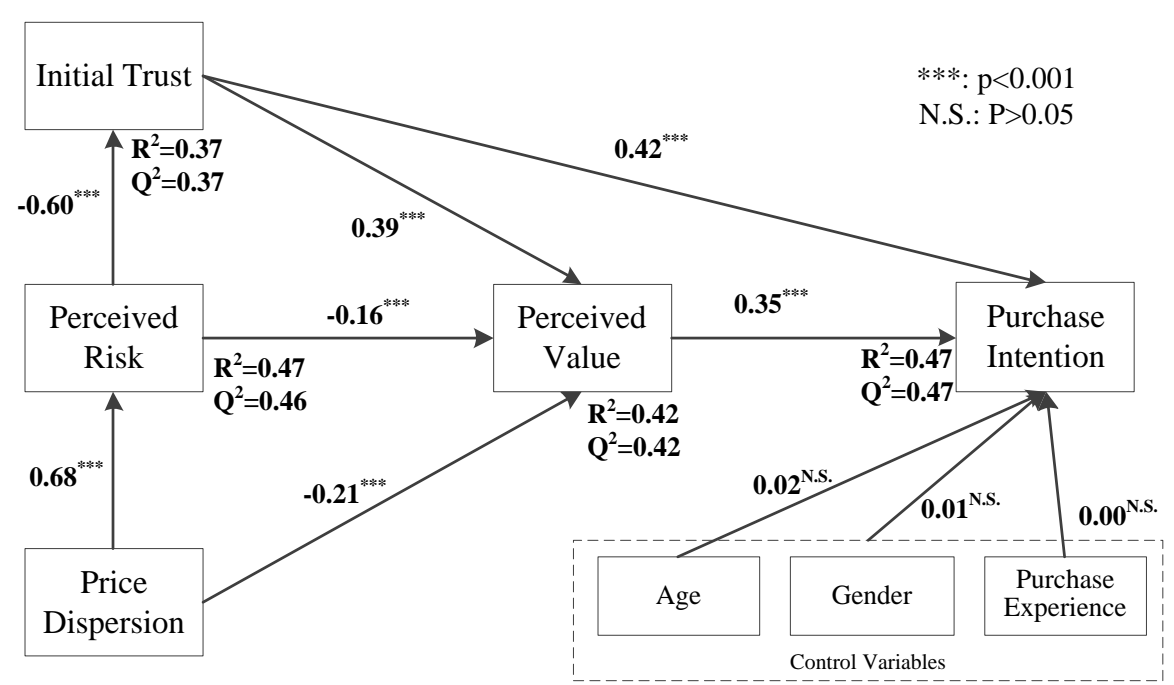

Figure 2 Results of structural model 

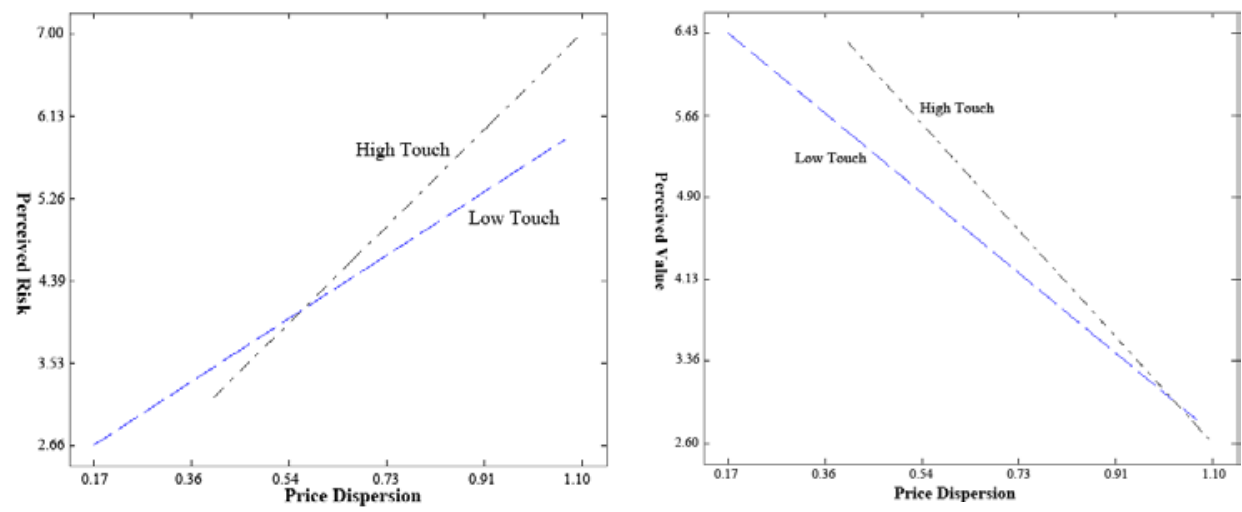

Figure 3 Moderating effects of product type 
Table 1. A brief summary of sources and effects of online price dispersion

\begin{tabular}{|c|c|c|}
\hline Categories & Sub-categories & Studies \\
\hline \multirow[t]{3}{*}{$\begin{array}{l}\text { Sources of online price } \\
\text { dispersion }\end{array}$} & Search Cost & $\begin{array}{l}\text { Search cost (In-Site/Cross-site) (Walter et al., 2006) } \\
\text { Evaluation Cost (Walter, et al., 2006) }\end{array}$ \\
\hline & $\begin{array}{l}\text { Product } \\
\text { Service }\end{array}$ & $\begin{array}{l}\text { Product cost structure (Walter, et al., 2006) } \\
\text { Price discrimination (Pan, et al., 2002) } \\
\text { Brand loyalty (Pan, et al., 2002) } \\
\text { Trust and reputation (Brynjolfsson \& Smith, 2000; Maxwell et } \\
\text { al., 2011) } \\
\text { Pricing strategy (Ghose et al., 2007) } \\
\text { Product information quality (Chung et al., 2006) } \\
\text { Product and service differentiation (Clemons et al., 2002) } \\
\text { Service quality (Pan, et al., 2002) } \\
\text { Product condition (Prieto et al., 2015) } \\
\text { Price format (Chellappa et al., 2011) }\end{array}$ \\
\hline & Market & $\begin{array}{l}\text { Number of competitors (Bock et al., 2007) } \\
\text { Product popularity (Pan, et al., 2004) } \\
\text { Maturity (Bock, et al., 2007) } \\
\text { Product price level (Maxwell, et al., 2011) }\end{array}$ \\
\hline $\begin{array}{l}\text { Effects of online price } \\
\text { dispersion }\end{array}$ & - & $\begin{array}{l}\text { Transaction Risk (Biswas \& Burman, 2009) } \\
\text { Search Amount/Intention (Biswas, 2004) } \\
\text { Internal reference price (Chen \& Bei, 2005; Lai, et al., 2006) }\end{array}$ \\
\hline
\end{tabular}

Table 2. Types of perceived risk

\begin{tabular}{|l|l|l|}
\hline Risk Type & Description & Example (C2C context) \\
\hline $\begin{array}{l}\text { Performance } \\
\text { risk }\end{array}$ & $\begin{array}{l}\text { The possibility that the purchased products cannot function } \\
\text { well or can be used for only a short period of time }\end{array}$ & $\begin{array}{l}\text { The product comes from } \\
\text { unknown factory and its quality } \\
\text { is not good. }\end{array}$ \\
\hline Social risk & $\begin{array}{l}\text { The possibility that buyer's important friends/family/work } \\
\text { group do not support the online shopping behavior }\end{array}$ & $\begin{array}{l}\text { Friends do not recommend the } \\
\text { buyer to purchase cell phone in } \\
\text { the market }\end{array}$ \\
\hline Time risk & $\begin{array}{l}\text { The possibility that the buyer may suffer from time loss and } \\
\text { inconvenience due to the delays of receiving the products } \\
\text { and return of unsatisfactory products }\end{array}$ & $\begin{array}{l}\text { The time used to return product } \\
\text { back to the vendor/factory is too } \\
\text { long }\end{array}$ \\
\hline Financial risk & $\begin{array}{l}\text { The possibility that the buyer may face monetary loss during } \\
\text { online shopping }\end{array}$ & $\begin{array}{l}\text { Unreliable money transfer, } \\
\text { product reparation cost }\end{array}$ \\
\hline Privacy risk & $\begin{array}{l}\text { The possibility that the buyer's personal information may be } \\
\text { used without permission }\end{array}$ & $\begin{array}{l}\text { Cell phone number or home } \\
\text { address sold to 3 }{ }^{\text {rd }} \text { party without } \\
\text { permission }\end{array}$ \\
\hline Physical risk & $\begin{array}{l}\text { The possibility that the product contains harmful ingredients } \\
\text { Shoes or clothes give off } \\
\text { irritating smell }\end{array}$ \\
\hline
\end{tabular}




\begin{tabular}{|l|l|l|}
\hline $\begin{array}{l}\text { Psychological } \\
\text { risk }\end{array}$ & $\begin{array}{l}\text { The possibility that the buyer suffer mental stress because of } \\
\text { their online shopping behavior }\end{array}$ & $\begin{array}{l}\text { The buyer feels frustrated if the } \\
\text { purchase is not successful }\end{array}$ \\
\hline
\end{tabular}

Table 3. Demographic information of participants

\begin{tabular}{|c|c|c|c|}
\hline Profile & Characteristic & Number of participants & Percentage \\
\hline \multirow{3}{*}{$\begin{array}{l}\text { 1.Age } \\
\text { Mean: 21.96; S.D.: } 0.96\end{array}$} & 18 to 21 & 37 & $14.1 \%$ \\
\hline & 22 to 25 & 222 & $85.1 \%$ \\
\hline & $\geq 26$ & 2 & $0.8 \%$ \\
\hline \multirow{2}{*}{$\begin{array}{l}\text { 2.Gender } \\
\text { Mean: 0.471; S.D.: } 0.50\end{array}$} & Female & 138 & $52.9 \%$ \\
\hline & Male & 123 & $47.1 \%$ \\
\hline \multirow[t]{3}{*}{ 3. Education } & Bachelor's: Grade 1 to 2 & 71 & $27.2 \%$ \\
\hline & Bachelor's: Grade 3 to 4 & 189 & $72.4 \%$ \\
\hline & Master's & 1 & $0.4 \%$ \\
\hline \multirow{4}{*}{$\begin{array}{l}\text { 4. Years of C2C } \\
\text { experience }\end{array}$} & Less than 6 months & 43 & $16.5 \%$ \\
\hline & 6 month to 1 year & 38 & $14.5 \%$ \\
\hline & 1 to 3 years & 65 & $24.9 \%$ \\
\hline & More than 3 years & 115 & $44.1 \%$ \\
\hline \multirow{7}{*}{$\begin{array}{l}\text { 5. Online C2C purchase } \\
\text { experience ( } 7 \text { point scale) } \\
\text { Mean: 4.874; S.D.:1.028 }\end{array}$} & Never & 0 & $0 \%$ \\
\hline & Very rarely & 4 & $1.5 \%$ \\
\hline & Rarely & 16 & $6.1 \%$ \\
\hline & Occasionally & 73 & $28.0 \%$ \\
\hline & Sometimes & 95 & $36.4 \%$ \\
\hline & Frequently & 62 & $23.8 \%$ \\
\hline & Very Frequently & 11 & $4.2 \%$ \\
\hline
\end{tabular}

Table 4. Measureable items for each construct

\begin{tabular}{|c|c|c|c|}
\hline Construct & Item & Content & Source \\
\hline \multirow{7}{*}{$\begin{array}{l}\text { Perceived } \\
\text { Risk } \\
\text { (Formative) }\end{array}$} & & If I purchase this product from sellers in this marketplace, ... & \multirow{7}{*}{$\begin{array}{l}\text { (Chang \& } \\
\text { Wu, 2012; } \\
\text { Ko, et al., } \\
2004 \text { ) }\end{array}$} \\
\hline & RISK1 & The product might fail to perform to my satisfaction. (Performance Risk) & \\
\hline & RISK2 & My friends or relatives will judge my purchase. (Social Risk) & \\
\hline & RISK3 & $\begin{array}{l}\text { The product might cause danger to my health or safety, for example, } \\
\text { poor quality of its material. (Physical Risk) }\end{array}$ & \\
\hline & RISK4 & $\begin{array}{l}\text { I might waste my time or effort getting the product repaired or replaced. } \\
\text { (Time Risk) }\end{array}$ & \\
\hline & RISK5 & $\begin{array}{l}\text { The purchase might have a negative effect on my peace of mind. } \\
\text { (Psychological Risk). }\end{array}$ & \\
\hline & RISK6 & $\begin{array}{l}\text { I might probably lead to a financial loss because of its poor warranty, } \\
\text { high delivery costs, or high transaction costs when I transfer money to } \\
\text { the seller. (Financial Risk) }\end{array}$ & \\
\hline
\end{tabular}




\begin{tabular}{|c|c|c|c|}
\hline & RISK7 & $\begin{array}{l}\text { The purchase would probably lead to a security or privacy loss for me } \\
\text { because my personal information (e.g., credit card, address) would be } \\
\text { disclosed. (Privacy Risk) }\end{array}$ & \\
\hline \multirow{3}{*}{$\begin{array}{l}\text { Initial Trust } \\
\text { (Reflective) }\end{array}$} & TRU1 & The sellers of this product seems to be trustworthy. & \multirow{3}{*}{$\begin{array}{l}\text { (Hu et al., } \\
2010 \text { ) }\end{array}$} \\
\hline & TRU2 & $\begin{array}{l}\text { The sellers of this product appears to be those who would keep promises } \\
\text { and commitments. }\end{array}$ & \\
\hline & TRU3 & I find that it is necessary to be cautious with these sellers (R). & \\
\hline \multirow{4}{*}{$\begin{array}{l}\text { Perceived } \\
\text { Value } \\
\text { (Reflective) }\end{array}$} & & If I purchase this product from sellers in this marketplace, ... & \multirow{4}{*}{$\begin{array}{l}\text { (Kim, et } \\
\text { al., 2012) }\end{array}$} \\
\hline & VAL1 & The money I pay for is a good deal & \\
\hline & VAL2 & The effort I make in shopping is worthwhile & \\
\hline & VAL3 & The risk involved in shopping at this store is of value & \\
\hline \multirow{4}{*}{$\begin{array}{l}\text { Purchase } \\
\text { Intention } \\
\text { (Reflective) }\end{array}$} & INT1 & $\begin{array}{l}\text { The probability that I would consider buying this product from this list of } \\
\text { sellers is high }\end{array}$ & \multirow{4}{*}{$\begin{array}{l}\text { (Kim, et } \\
\text { al., 2012; } \\
\text { Pavlou \& } \\
\text { Gefen, } \\
2004)\end{array}$} \\
\hline & INT2 & $\begin{array}{l}\text { If I were to buy this product, I would consider buying it from this list of } \\
\text { sellers }\end{array}$ & \\
\hline & INT3 & My willingness to buy this product from this list of sellers is high & \\
\hline & INT4 & $\begin{array}{l}\text { It is likely that I will purchase this product from sellers in this list in the } \\
\text { near future }\end{array}$ & \\
\hline $\begin{array}{l}\text { Price } \\
\text { Dispersion }\end{array}$ & DIS1 & $\begin{array}{l}\text { The range (higest price minus lowest price) divided by the average price } \\
\text { for a particular product }\end{array}$ & $\begin{array}{l}\text { (Pan, et al., } \\
\text { 2004) }\end{array}$ \\
\hline
\end{tabular}

Table 5. Results for measurement model

\begin{tabular}{|c|c|c|c|c|c|c|c|c|}
\hline Construct & Items & Mean & S.D. & Loading & C.R. & C.A. & AVE & VIF \\
\hline \multirow[t]{3}{*}{ Initial Trust } & TRU1 & 5.073 & 1.163 & 0.853 & \multirow[t]{3}{*}{0.910} & \multirow[t]{3}{*}{0.852} & \multirow[t]{3}{*}{0.772} & \multirow[t]{3}{*}{2.154} \\
\hline & TRU2 & 5.046 & 1.136 & 0.881 & & & & \\
\hline & TRU3 & 4.885 & 1.131 & 0.901 & & & & \\
\hline \multirow[t]{7}{*}{ Perceived Risk ${ }^{\mathrm{a}}$} & RISK1 & 4.146 & 1.260 & 0.753 & \multirow[t]{7}{*}{ N/A } & \multirow[t]{7}{*}{ N/A } & \multirow[t]{7}{*}{ N/A } & \multirow[t]{7}{*}{2.501} \\
\hline & RISK2 & 4.165 & 1.215 & 0.807 & & & & \\
\hline & RISK3 & 4.004 & 1.236 & 0.791 & & & & \\
\hline & RISK4 & 4.130 & 1.237 & 0.778 & & & & \\
\hline & RISK5 & 4.272 & 1.179 & 0.784 & & & & \\
\hline & RISK6 & 4.077 & 1.035 & 0.812 & & & & \\
\hline & RISK7 & 4.123 & 1.120 & 0.798 & & & & \\
\hline Price Dispersion & DIS1 & 2.441 & 0.867 & 1.000 & 1.000 & 1.000 & 1.000 & 2.479 \\
\hline \multirow[t]{3}{*}{ Perceived Value } & VAL1 & 5.226 & 1.205 & 0.841 & \multirow[t]{3}{*}{0.881} & \multirow[t]{3}{*}{0.797} & \multirow[t]{3}{*}{0.712} & \multirow[t]{3}{*}{2.004} \\
\hline & VAL2 & 4.663 & 1.228 & 0.812 & & & & \\
\hline & VAL3 & 5.157 & 1.187 & 0.876 & & & & \\
\hline \multirow[t]{3}{*}{ Purchase Intention } & INT1 & 5.165 & 1.286 & 0.857 & \multirow[t]{3}{*}{0.905} & \multirow[t]{3}{*}{0.859} & \multirow[t]{3}{*}{0.704} & \multirow[t]{3}{*}{2.272} \\
\hline & INT2 & 5.230 & 1.170 & 0.845 & & & & \\
\hline & INT3 & 5.180 & 1.269 & 0.868 & & & & \\
\hline
\end{tabular}




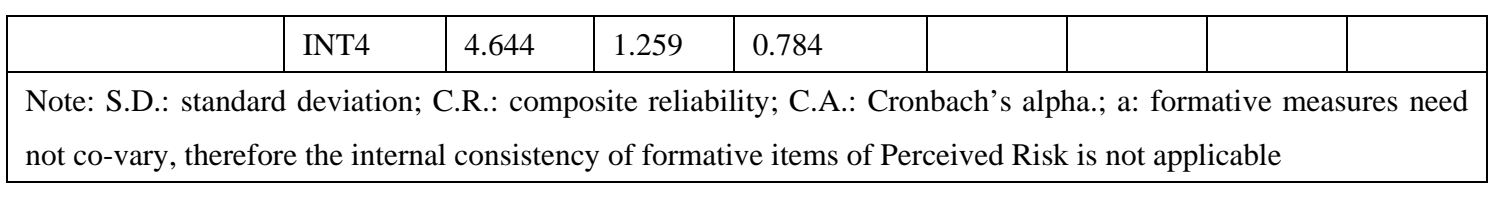

Table 6. Correlations among constructs

\begin{tabular}{|l|l|l|l|l|l|}
\hline Construct & \multicolumn{1}{|c|}{$\mathbf{1}$} & \multicolumn{1}{|c|}{$\mathbf{2}$} & \multicolumn{1}{|c|}{$\mathbf{3}$} & \multicolumn{1}{|c|}{$\mathbf{4}$} & $\mathbf{5}$ \\
\hline 1.Initial Trust & $(0.879)$ & & & & \\
\hline 2.Perceived Risk & -0.604 & $(0.789)$ & & & \\
\hline 3.Price Dispersion & -0.447 & 0.671 & $(1.000)$ & & \\
\hline 4.Perceived Value & 0.578 & -0.543 & -0.484 & $(0.844)$ & \\
\hline 5.Purchase Intention & 0.624 & -0.561 & -0.606 & 0.590 & $(0.839)$ \\
\hline
\end{tabular}

Note: Values on the diagonal are the square root of the average variance extracted (AVE) for each construct.

Table 7. Results of model fitness

\begin{tabular}{|l|l|l|}
\hline Fitness Indices & Value in our study & Recommended Threshold \\
\hline Average path coefficient (APC) & $0.253, \mathrm{P}<0.001$ & $\mathrm{P}<0.05$ \\
\hline Average R-squared (ARS) & $0.430, \mathrm{P}<0.001$ & $\mathrm{P}<0.05$ \\
\hline Average adjusted R-squared & $0.423, \mathrm{P}<0.001$ & $\mathrm{P}<0.05$ \\
\hline Average block VIF (AVIF) & 1.363 & $\mathrm{AVIF}<=3.3$ \\
\hline Average full collinearity VIF (AFVIF) & 1.695 & $\mathrm{AFVIF}<=3.3$ \\
\hline Tenenhaus GoF (GoF) & 0.615 & $\mathrm{GoF} \geqslant 0.36$ \\
\hline Sympson's paradox ratio (SPR) & 0.917 & $\mathrm{SPR}>=0.7$. \\
\hline R-squared contribution ratio (RSCR) & 1.000 & $\mathrm{RSCR}>=0.9$ \\
\hline Statistical suppression ratio (SSR) & 1.000 & $\mathrm{SSR}>=0.7$ \\
\hline Nonlinear bivariate causality direction ratio (NLBCDR) & 0.833 & $\mathrm{NLBCDR}>=0.7$ \\
\hline
\end{tabular}

